\title{
Permanent Preservation Areas scenarios in dairy farms in the Vale do Taquari against the Forest Code
}

\author{
Cenário das áreas de preservação permanente em \\ propriedades rurais produtoras de leite no Vale do \\ Taquari ante o Código Florestal
}

Caio Zart Daiello

Claudete Rempel ${ }^{\mathbf{b}}$

${ }^{a}$ Master in Sustainable Environmental Systems, Universidade do Vale do Taquari - Univates, Lajeado, RS, Brazil. E-mail: caiodaiello@universo.univates.br

${ }^{b}$ Doctor in Ecology, Universidade do Vale do Taquari - Univates, Lajeado, RS, Brazil. E-mail:crempel@univates.br

doi:10.18472/SustDeb.v11n1.2020.26753

Received: 20/08/2019

Accepted: 31/03/2020

ARTICLE- VARIA

\begin{abstract}
The present study sought to analyze the implications of innovations in the Permanent Preservation Areas (PPAs) regulation implemented by the New Forest Code (Law 12.651 / 2012). The use and cover of the PPAs of five milk producing rural properties, located in the Taquari Valley, RS, were identified and the rules of the Code were applied, in order to determine the areas that must be recovered and respected in each property. The research adopted the deductive approach, with a quali-quantitative methodological approach, and the technical procedures of field and case study were used. The results showed that the total areas to be respected represent $11.72 \%, 5.10 \%, 59.77 \%, 81.63 \%$ and $98.37 \%$ of the properties' PPAs, indicating that the innovations presented by the Code can cause significant reduction in the PPA to be respected, in addition to resulting in different protection measures among the properties, imposing greater burdens on those in which the native vegetation was more preserved.
\end{abstract}

Keywords: New Forest Code. Permanent Preservation Area. Consolidated Rural Area. Milk production. Taquari Valley.

\section{RESUMO}

O presente estudo buscou analisar as implicações das inovações no regramento das Áreas de Preservação Permanente (APPS) implementadas pelo Novo Código Florestal (Lei 12.651/2012). Foram identificados o uso e cobertura das APPs de cinco propriedades rurais produtoras de leite, localizadas no Vale do Taquari, RS, e aplicadas as regras do Código, a fim de determinar as áreas que devem ser recuperadas e respeitadas em cada propriedade. A pesquisa adotou o método dedutivo, com abordagem metodológica qualiquantitativa, e empregados os procedimentos técnicos de estudo de campo e estudo de caso. Os resultados apontaram que as áreas totais a serem respeitadas 
representam $11,72 \%, 5,10 \%, 59,77 \%, 81,63 \%$ e 98,37\% das APPs das propriedades, indicando que as inovações trazidas pelo Código podem ocasionar significativa redução na APP a ser respeitada, além de acarretarem medidas de proteção díspares entre as propriedades, impondo ônus maiores àquelas em que a vegetação nativa foi mais preservada.

Palavras-Chave: Novo Código Florestal. Área de Preservação Permanente. Área rural consolidada. Produção de leite. Vale do Taquari.

\section{INTRODUCTION}

According to Law 12.651/2012, which established the Law on the Protection of Native Vegetation, known as the New Forest Code (BRASIL, 2012a), Permanent Preservation Areas (APPs) are considered, in rural or urban areas, among other locations, the marginal strips of any natural watercourse, the areas around lakes, lagoons, springs, slopes higher than 45, top of hills, paths.

These areas, which aim to protect places of great environmental importance, are, according to article 3 , item II of the New Forest Code, essential for the conservation of natural resources, maintenance of biodiversity and ensuring the well-being of human populations (BRASIL, 2012a). Among the places considered PPAs, the marginal strips of watercourses are often used in rural properties with milk production as a place for watering the cattle.

Brazil is the third largest world producer of cow milk, behind the United States and India. According to data from the Food and Agriculture Organization - FAO (2019), in 2017 the country produced 33.49 million tons of cow milk, which represented $4.95 \%$ of world production. In economic terms, the value of production that year represented $R \$ 37.099$ billion (IBGE, 2017), making the milk production chain a representative factor in the national economic scenario.

According to IBGE (2018), the national production is concentrated in the states of Minas Gerais, Rio Grande do Sul, Paraná, Goiás and Santa Catarina, which were responsible for approximately $72 \%$ of the total produced, using different systems of dairy cattle raising. The state of Rio Grande do Sul stands out in the sector, being the second largest milk producer in the country, responsible for $13.59 \%$ of the national production (IBGE, 2017). The Taquari Valley is the third region that most produces fresh milk in the state, handling $8 \%$ of state production (FEE, 2015a).

In a study on water quality in milk producing rural properties in the Taquari Valley, Bortoli et al. (2017) found that watercourse margin PPAs have free access to livestock, increasing the chances of contamination by coliforms from water sources due to the feces carried by the animal, in addition to the trampling of cattle in the seedlings and shoots of vegetation, which ends up not regenerating.

The vegetation cover in the watercourse margin PPAs works attenuating the erosive effects and the leaching of the soil, contributing to the regularization of the water flow, reducing the silting of the river courses and reservoirs, as well as bringing benefits to the fauna (COSTA, SOUZA and BRITES, 1996).

For Rodrigues, Campanhola and Kitamura (2003) the concept of sustainability is related to sustainable rural development, where an increase in production and income is expected, with the aim of improving the quality of life and work in the agricultural space, in addition to generating positive impacts for the environment.

The concept of sustainability, first coined at the Stockholm Conference in 1972 (COMISSÃO, 1991), refers to the principle of seeking a balance between the availability of natural resources and their exploitation by society. In other words, it aims to balance the preservation of the environment and what it can offer in line with the population's quality of life. This way, the preservation, conservation, and recovery of plant areas meet the search for sustainability. 
Although the New Forest Code provides for specific extensions to be respected in each type of PPA, it also contemplates a series of exceptions, limitations, management possibilities and continuity of use in certain situations. Among these, there is the rule about the so-called Consolidated Rural Areas, which refer to the anthropic occupation of PPA on July 22, 2008. In such cases, the continuation of agroforestry, ecotourism and rural tourism activities is authorized, requiring only the recovery of a strip of the PPA next to the watercourse.

This research seeks to contribute to clarifying the implications that the innovations brought by the New Forest Code represent for PPAs in watercourses, as well as the possible consequent environmental damage. Considering that the deadline for joining the Environmental Regularization Program has not yet ended, it is even more necessary to examine how compliance with this law will take place.

The hypothesis of the present study is that, in the properties where the Consolidated Rural Area occupies a large portion of the PPA, the area that will have to be respected will be significantly reduced, since the width of the strip to be recomposed is determined solely by the size of the property, and not by the width of the watercourse.

\section{METHODOLOGICAL PROCEDURES}

\subsection{AREA OF STUDY AND CHARACTERIZATION OF RURAL PROPERTIES IN THE TAQUARI VALLEY}

The state of Rio Grande do Sul (RS) represents an important link in the national milk production chain throughout its territory. In 2014, fresh milk production was mainly concentrated in the northern half of the state. The regions with the highest production were Northwest Border (9.1\%), Production (8.8\%) and Taquari Valley (7.9\%), in which are also the municipalities with the highest productivity indexes (IBGE, 2017).

The study area comprises the geopolitical region called Taquari Valley (TV), which consists of 36 municipalities and occupies approximately $2 \%$ of the State's territory (FEE, 2015a). Its physiognomic characteristics are varied, being partly in the lower slope of the Southern Plateau, partly in the Central Depression in the State of Rio Grande do Sul and another in the Campos de Cima da Serra (REMPEL, 2012). It has as vegetation formations Mixed Ombrophilous Forest and Deciduous Seasonal Forest, both components of the Atlantic Forest (BORTOLI et al., 2017).

Due to its importance for the regional economic dynamics, the production of milk and dairy products has played a prominent role in the development of the TV (FEIX, JORNADA; GASPERI, 2015). In its territory is also located approximately $1 / 1 /$ (a quarter) of the state's industrial employment in the activities of preparing milk and manufacturing dairy products and other derivatives (FEE, 2015a).

Milk producing rural properties that participate in the research "Sustainability of milk producing properties", developed at the Universidade do Vale do Taquari - Univates, were evaluated. The research group studies the sustainability (social, environmental and economic aspects) of 124 rural properties in all 36 municipalities in the TV region, the number of properties per city being determined according to the milk productivity percentage of each municipality. The properties participating in the research were indicated by the Agriculture Secretariats and Emater of each municipality. Figure 1 shows the location of the studied region, as well as the number of properties evaluated in each municipality. It is worth mentioning that the geographical position of each property is not mentioned due to a partnership agreement established between the researchers and the producers participating in the research. 


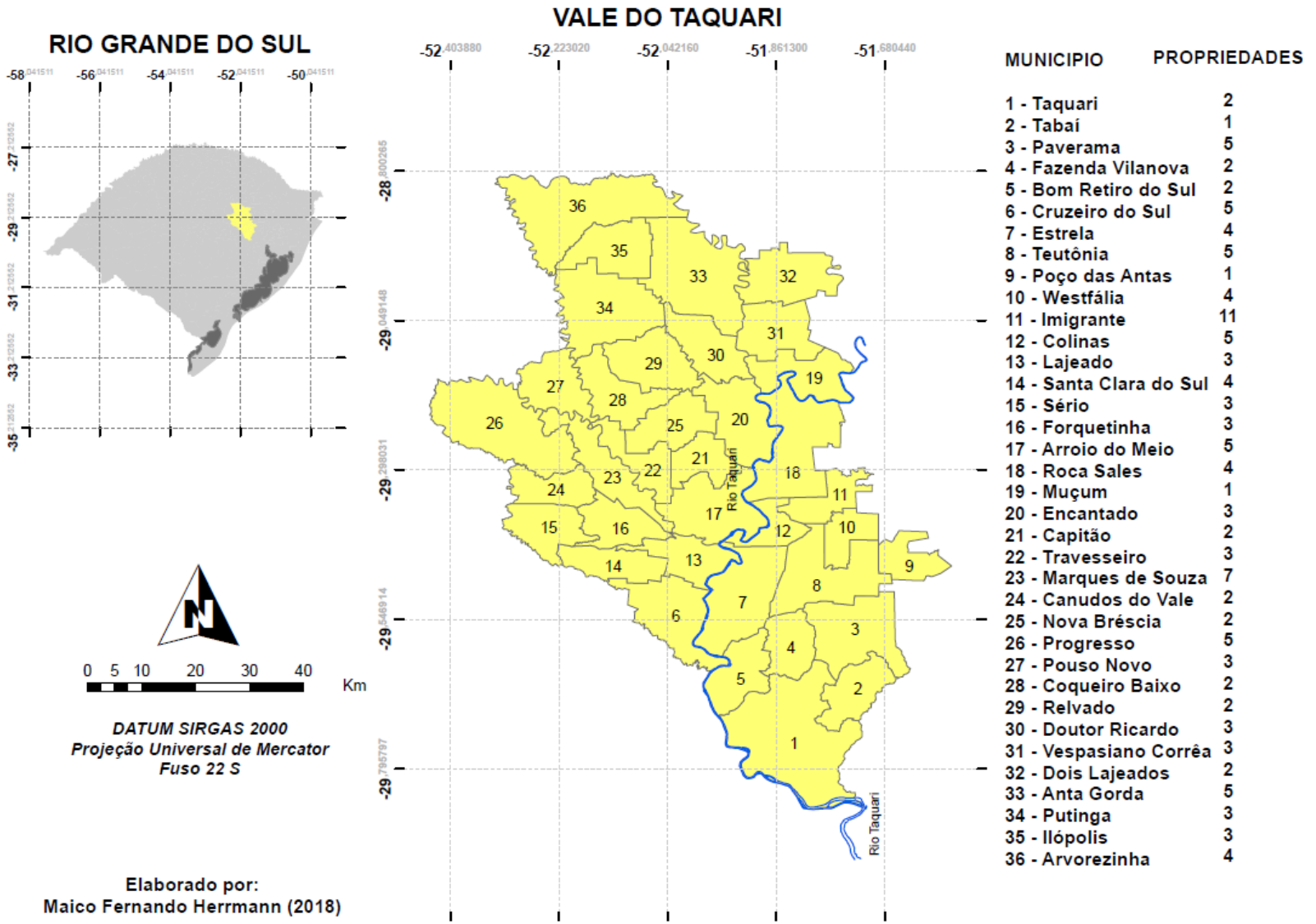

Figure 1 | Location of the Taquari Valley region with the determination of the number of properties evaluated in each municipality.

Source: Data from the Research group (2019).

Among the sustainability aspects assessed by the group, the use and cover of PPAs was one of the items of greatest value considered. Having 15 points as a maximum score (out of a total of 100 points), the average evaluation of this parameter reached 6.4 (SD 2.5). This low score occurred in a large part of the 36 municipalities of the TV, of which, 25 did not reach $50 \%$ of the maximum allowed score, a preoccupying fact, since if there is no preservation of native vegetation, all water resources of the properties will suffer impacts (REMPEL et al, 2017).

\subsection{DATA COLLECTION}

Initially, the current situation of land use and cover in PPA in the properties participating in the project, as previously mentioned, "Sustainability in milk producing rural properties", by Univates, was established.

The methodology for making and characterizing the property maps, with the delimitations of their PPAs, followed the following steps: 1) Selection of properties; 2) Visit to the properties; 3) Data collection with the owner; 4) Taking of geographical coordinates and types of occupations; 5) Capture of the images of the properties in the Google Earth PRO software; 6) Making the map in AutoCAD software; 7) Tabulation of data in Microsoft Excel software; 8) Analysis of the use and occupation of properties and their PPAs; 9) Finalization of the map with the percentage of land occupations.

The project has already evaluated the environmental sustainability of 124 properties based on 9 parameters, including the status of their PPAs, as shown in Table 1. 
Table 1 | Environmental sustainability assessment parameters.

\begin{tabular}{|c|c|l|c|c|}
\hline Parameters & Score & \multicolumn{1}{|c|}{ Subparameter } & \multicolumn{1}{|c|}{ Score } & $\%$ \\
\hline WASTE & 20 & Solid waste storage & 10 & 20 \\
\hline & & Storage of liquid waste & 5 & 5 \\
\hline WATER & 10 & $\begin{array}{l}\text { Wasposal of animal waste } \\
\text { Water source for human consumption }\end{array}$ & 5 & 10 \\
\hline PPA & 15 & Percentage of use of PPAs & 10 & 15 \\
\hline & & Predominant use in the PPA & 5 & 10 \\
\hline LEGAL RESERVE & 10 & Percentage of native vegetation for annotation in legal reserve & 10 & 15 \\
\hline PESTICIDES AND & 15 & Use of chemical fertilizers and pesticides & 10 \\
\hline FERTILIZERS & & Pesticide packaging storage & 5 & 10 \\
\hline SLOPE & 10 & Land slope & 5 & 5 \\
\hline EROSION & 5 & Evidence of eroded soil & 5 & 5 \\
\hline BURNINGS & 5 & Evidence of burnings & 10 & 10 \\
\hline LAND USES & 10 & Cover diversity & 100 & 100 \\
\hline TOTALS & - & - & 5 & 10 \\
\hline
\end{tabular}

Source: Adapted from Rempel et al. (2012) and Verona (2008).

The score given to the situation of PPAs was made up of two subparameters: the percentage of use of PPAs and their predominant use. The result determined a rate among five categories: Excellent, Good, Regular, Bad and Very bad.

Table 2 | Subparameter percentage of use of PPAs.

\begin{tabular}{|c|c|c|}
\hline Status & Score & Rate \\
\hline $0 \%$ & 10 & Excellent \\
\hline 1 to $30 \%$ & 7.5 & Good \\
\hline 31 to $55 \%$ & 5 & Regular \\
\hline 56 to $80 \%$ & 2.5 & Bad \\
\hline 81 to $100 \%$ & 0 & Very Bad \\
\hline
\end{tabular}

Source: Adapted from Rempel et al. (2012) and Verona (2008).

Table 3 | Subparameter of the predominant use of PPA.

\begin{tabular}{|c|c|c|}
\hline Status & Score & Rate \\
\hline Native Forest & 5 & Excellent \\
\hline Permanent crops and exotic forest & 3.75 & Good \\
\hline Pasture areas & 2.5 & Regular \\
\hline Agriculture & 1.25 & Bad \\
\hline Improvements & 0 & Very Bad \\
\hline
\end{tabular}

Source: Adapted from Rempel et al. (2012) and Verona (2008).

After examining the results obtained by the project, one property rated in each of the five categories mentioned in the PPA parameter was selected by lot. Only one property was rated Excellent in this parameter, which made its choice compelling, eliminating the need to draw for this rate. 
Once the properties were selected, a second map of each property was made in order to ascertain the status of the use and cover of their PPAs on July 22, 2008. For this, images of the properties were collected through the application called "Registration Module", provided on the website of the Rural Environmental Registry (CAR). The system uses images obtained until July 22, 2008, which is the date provided for in the New Forest Code for the characterization of consolidated rural areas.

In the application, the image of the municipality in which the property is located was first downloaded, from which the entire area of the property is delimited, which provides options for characterizing their occupations, which are: Ground Cover (fallow areas, remnant of native vegetation and consolidated areas), Administrative easement (public works), PPA or Restricted Use and Legal Reserve.

Once this identification was made, the property maps were finalized, and their data tabulated. In order to make them, the same delineations of the properties and their current PPAs were used, since their characterization in face of the provisions of the New Forest Code, especially the size of the properties and the location of their consolidated rural areas, result from their current situation.

Once the existence of a consolidated rural area on the property was found, it was necessary to investigate the use and cover of the recovery strips, according to the limits set forth in Article 61-A of the Code. For this, the same images used to check the current status of their PPAs, collected between November and December 2018, were used, applying the same procedures described at the beginning of this section to identify the use and cover in these strips, with the making of respective maps and data tabulation.

\subsection{DATA ANALYSIS}

In order to identify the situation of the properties in view of the rules related to the PPAs foreseen in the New Forest Code, as well as any necessary recovery measures, the starting point was the analysis of the maps of the current condition of their PPAs, based on images of the properties collected between November and December 2018. The maps show the delimitations of the PPAs of the five properties in accordance with the general rule of PPAs in marginal strips of water courses, provided for in item I of article 4 of the New Forest Code.

If any property was fully in accordance with the general rule, that is, that its PPAs were fully covered by native vegetation, the analysis would be closed at this stage, since no recovery measures would be necessary. In this case, the property should respect its current situation, maintaining native vegetation throughout its PPAs. However, no property had this condition, which is why it was necessary to apply the following steps to all of them.

Since the property is not in full compliance with the general rule of PPAs protection, the analysis of maps containing the use and cover of their PPAs in 2008 was carried out. In this stage, the existence of a consolidated rural area in the PPAs was verified, defined by article 3, item IV of the New Forest Code as the "rural area with pre-existing human occupation on July 22, 2008, with buildings, improvements or agroforestry activities, admitted, in the latter case, the adoption of the fallow regime" (BRASIL, 2012a), which was observed in all properties.

Once the presence of a consolidated rural area was verified, the next step was the analysis of the maps containing the use and cover of the restoration strips required by Article 61-A of the New Forest Code, elaborated based on the images of the properties from 2018. In order to determine the width of the strips, the number of fiscal modules representing the total area of the property 
was identified, observing the limits that the recovery area can reach in relation to the size of the property, in accordance with articles 61-A and 61-B of the New Forest Code, and article 19 of Decree 7830/2012, outlined in Chart 1.

Chart 1 | Measures to recompose PPAs in marginal strips of watercourses for properties with consolidated rural areas.

\begin{tabular}{|c|c|c|}
\hline Property Size & Recovery to be performed & $\begin{array}{c}\text { Maximum percentage of the property that the recom- } \\
\text { posed area can represent }\end{array}$ \\
\hline Up to 1 fiscal module & 5 meters & $10 \%$ \\
\hline 1 to 2 fiscal modules & 8 meters & $20 \%$ \\
\hline 2 to 4 fiscal modules & 15 meters & No limitation \\
\hline $\begin{array}{c}4 \text { to } 10 \text { fiscal modules, in } \\
\text { watercourses up to } 10 \text { meters wide }\end{array}$ & 20 meters & $\begin{array}{c}\text { Half the width of the } \\
\text { watercourse }\end{array}$ \\
\hline Other cases & . & \\
\hline
\end{tabular}

Source: Own elaboration, adapted from articles 61-A and 61-B of the New Forest Code (BRASIL, 2012a), and article 19, paragraph 4 of Decree 7830 (BRASIL, 2012f).

Based on these maps, the area to be recomposed was identified, excluding the area that is already covered by native vegetation within this range, considered as already recovered.

After determining the area to be recovered in the recovery strips, the identification of the area of the PPAs that must be respected outside these strips began. To this end, excluding the area of the recovery strips, the area occupied in the PPAs in 2008 and 2018 was compared, by activities that constitute a consolidated rural area. If there was an increase in this area, it was considered that this difference should be repaid and, therefore, should be counted as an area to be respected. If there was a reduction, its current situation was considered as an area to be respected, since the reconversion of the area recovered after 2008 is not allowed.

After that, the area to be recomposed within the recovery strip was added to the area to be respected outside that strip, in order to determine the total area of the PPA to be respected in each property. Figure 2 shows the data analysis flowchart. 


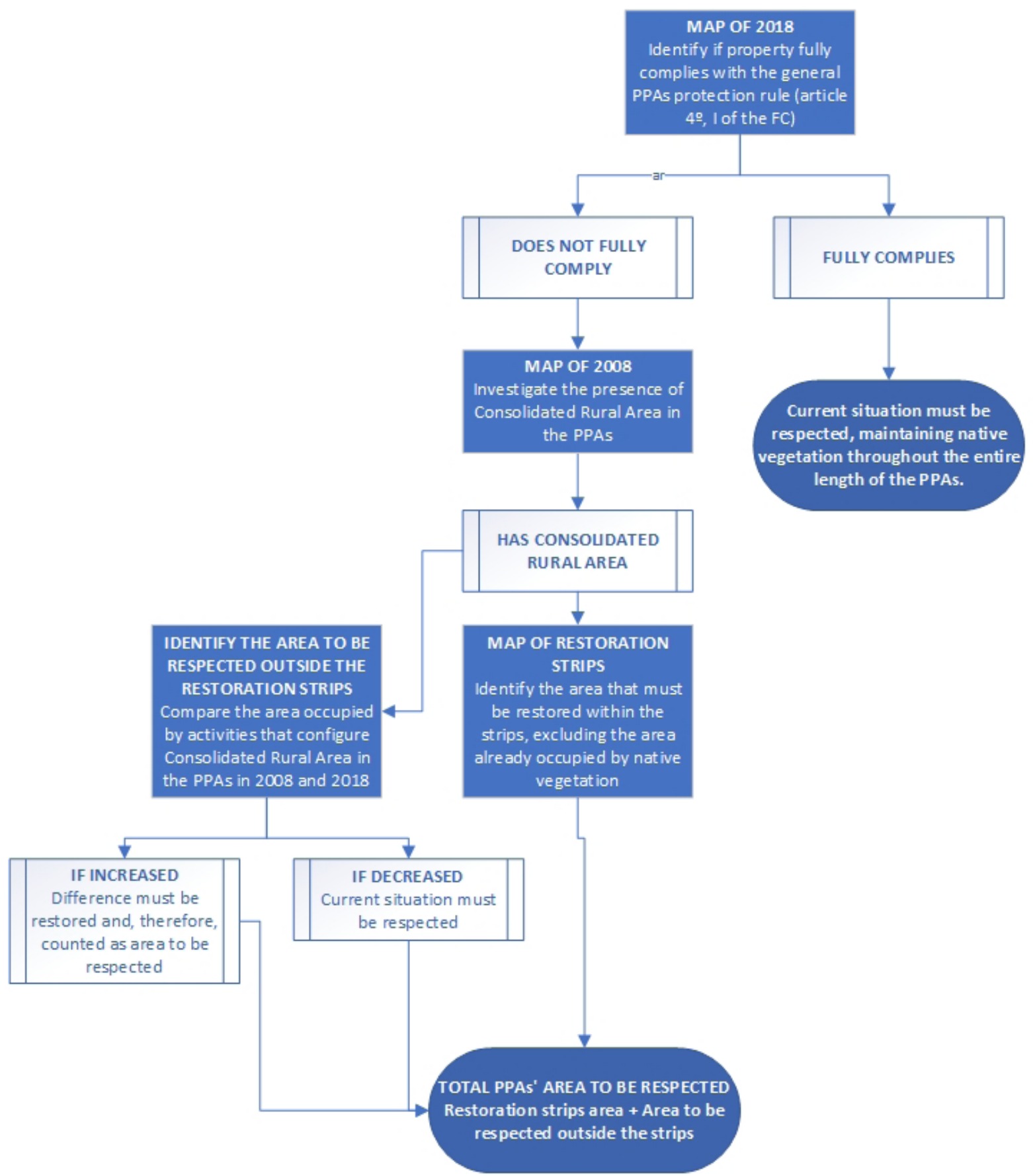

Figure 2 | Flowchart of the data analysis process.

Source: Own elaboration. 


\section{RESULTS}

The situation of the PPAs in the five selected milk producing properties, participating in the project "Sustainability in milk producing rural properties", was investigated through the data obtained through three maps of each.

The first, made from its 2018 image, portrayed the current situation of the use and cover of the PPAs. The second, made using the 2008 image, presented the use and cover of the PPAs in 2008. The third, also made from the 2018 image of each property, demonstrated the use and cover of the recovery strips provided for in Article 61-A of the New Forest Code.

Considering that the fiscal module in the Taquari Valley region varies between 18 and 20 hectares (INCRA, 2013), its average, 19 hectares, was considered as a fiscal module for the classification of properties in the provisions of the Code, in order to preserve confidentiality about the location of the properties.

\subsection{PROPERTY RATED VERY BAD}

Table 4 presents the situation of the use and cover of PPAs of the property rated Very Bad in the PPA parameter, in the project "Sustainability in milk producing rural properties", in 2018 and 2008.

Table 4 | Use of PPAs in the property rated Very Bad in the PPA parameter.

\begin{tabular}{|c|c|c|c|c|}
\hline & \multicolumn{2}{|c|}{ Status in 2018} & \multicolumn{2}{c|}{ Status in 2008} \\
\hline USE OF PPAS & Area $\left(\mathrm{m}^{2}\right)$ & Percentage & Area $\left(\mathrm{m}^{2}\right)$ & Percentage \\
\hline PASTURE & $9,659.57$ & $50,66 \%$ & $15,621.61$ & $81.94 \%$ \\
\hline CORN & $2,125.43$ & $11.14 \%$ & $2,596.30$ & $13.61 \%$ \\
\hline IMPROVEMENTS & $7,280.02$ & $38.18 \%$ & 847.11 & $4.45 \%$ \\
\hline
\end{tabular}

Source: Research data (2019).

In 2008, the property's PPAs did not have any area with native forest, being used, in its entirety, in agroforestry activities and with improvements. Therefore, the use of APPs, in all its extension, is characterized as a consolidated rural area, according to item IV of article 3 of the New Forest Code. The 2018 data show that its destination remains unchanged, with variation only in the proportions of its use.

Once there is a consolidated rural area, represented by agroforestry activities, it is necessary to verify the measure to be recomposed according to the transition rule provided for in article 61-A of the New Forest Code. All the property's PPAs result from the presence of watercourses.

The property has between 1 and 2 fiscal modules, making the restoration of the marginal strips to be at 8 meters, counting from the channel of the regular bed of the watercourses, as shown in Table 1. Table 5 shows the use and cover of these strips on the property.

Table 5 | Use of recovery strips in the property rated Very Bad in the PPA parameter.

\begin{tabular}{|c|c|c|}
\hline Use of the strips & Area $\left(\mathrm{m}^{2}\right)$ & Percentage \\
\hline PASTURE & $1,097.20$ & $49.09 \%$ \\
\hline CORN & 293.11 & $13.12 \%$ \\
\hline IMPROVEMENTS & 844.54 & $37.79 \%$ \\
\hline
\end{tabular}

Source: Research data (2019). 
Considering that the recovery strips do not have any native vegetation, they must be fully recovered. According to Table 5, the areas of these strips add up to $2,234.85 \mathrm{~m}^{2}$, which corresponds to $11.72 \%$ of the total area of the property's PPAs, of $19,065.02 \mathrm{~m}^{2}$.

All the rest of its PPAs are in a consolidated rural area and continue to be used, which is why the recovery strips will be the only part of its PPAs that will need to be respected, and activities can be maintained for the rest of its extension.

\subsection{PROPERTY RATED BAD}

Table 6 shows the percentages and the area of use and cover of PPAs in the property rated Bad, in 2018 and 2008.

Table 6 | Use of PPAs in the property rated Bad in the PPA parameter.

\begin{tabular}{|c|c|c|c|c|}
\hline & \multicolumn{2}{|c|}{ Status in 2018} & \multicolumn{2}{c|}{ Status in 2008} \\
\hline $\begin{array}{c}\text { USE OF } \\
\text { PPAS }\end{array}$ & Area $\left(\mathrm{m}^{2}\right)$ & Percentage & Area $\left(\mathrm{m}^{2}\right)$ & Percentage \\
\hline $\begin{array}{c}\text { EXOTIC } \\
\text { FOREST }\end{array}$ & $10,541.79$ & $29.13 \%$ & $14,495.16$ & $40.06 \%$ \\
\hline PASTURE & $25,642.53$ & $70.87 \%$ & $21,689.16$ & $59.94 \%$ \\
\hline
\end{tabular}

Source: Research data (2019).

The property's PPAs presented, in 2008, areas occupied by exotic forest and destined to pasture, without any native forest. Its destination in 2018 remained the same, only changing the percentages of its use.

Thus, with agroforestry activities being developed in the PPAs in 2008, the property presents a consolidated rural area. Both the portions occupied by pasture and by exotic forest were considered as a consolidated rural area, mainly because the latter is located next to the watercourse, often used for cattle watering on milk producing rural properties in the TV, as verified by Bortoli et al. (2017).

The property has between 1 and 2 fiscal modules, and a strip of 8 meters of its PPAs must be recomposed, starting from the edge of the regular bed of the watercourses. Table 7 presents data on the use and cover of these strips.

Table 7 | Use of recovery strips in the property rated Bad in the PPA parameter.

\begin{tabular}{|c|c|c|}
\hline Use of the strips & Area $\left(\mathrm{m}^{2}\right)$ & Percentage \\
\hline PASTURE & $1,846.14$ & $100 \%$ \\
\hline
\end{tabular}

Source: Research data (2019).

The 8-meter strips are occupied exclusively by pasture and must, therefore, be fully recomposed. The total area of these strips is $1,846.14 \mathrm{~m}^{2}$, which corresponds to $5.10 \%$ of the total area of its PPAs, of $36,184.32 \mathrm{~m}^{2}$.

Bearing in mind that the entire extension of the property's PPAs is a consolidated rural area, the only area to be respected will be that represented by the strips to be restored, and agroforestry activity in the rest of the PPAs can be maintained. 


\subsection{PROPERTY RATED REGULAR}

The use and cover situation of the PPAs of the property rated Regular, in 2018 and 2008, is presented in Table 8.

Table 8 | Use of PPAs in the property rated Regular in the PPA parameter.

\begin{tabular}{|c|c|c|c|c|}
\hline & \multicolumn{2}{|c|}{ Status in 2018} & \multicolumn{2}{c|}{ Status in 2008} \\
\hline USE OF PPAS & Area $\left(\mathrm{m}^{2}\right)$ & Percentage & Area $\left(\mathrm{m}^{2}\right)$ & Percentage \\
\hline NATIVE FOREST & $10,487.99$ & $49.70 \%$ & $9,711.29$ & $46.00 \%$ \\
\hline PASTURE & $9,164.91$ & $43.4 \%$ & $9,956.08$ & $47.20 \%$ \\
\hline IMPROVEMENTS & $1,308.30$ & $6.20 \%$ & $1,293.88$ & $6.10 \%$ \\
\hline
\end{tabular}

Source: Research data (2019).

In 2008, the use and cover of the property's PPAs had pasture and improvements, considered consolidated rural areas, in addition to native forest. The situation in 2018 presented the same destinations for PPAs, varying only the proportions of their uses.

The extension of the property represents between 1 and 2 fiscal modules, which requires the recovery of a strip of 8 meters, from the regular bed of its watercourses. The situation of these strips is shown in Table 9.

Table 9 | Use of recovery strips in the property rated Regular in the PPA parameter.

\begin{tabular}{|c|c|c|}
\hline Use of the strips & Area $\left(\mathrm{m}^{2}\right)$ & Percentage \\
\hline PASTURE & $2,162.97$ & $58.19 \%$ \\
\hline NATIVE FOREST & $1,553.88$ & $41.81 \%$ \\
\hline
\end{tabular}

Source: Research data (2019).

The data show that, in these 8 meters, $1,553.87 \mathrm{~m}^{2}$ already have native forest, while 2,162.97 $\mathrm{m}^{2}$ are occupied by pasture. Therefore, only this last area must be recomposed, since in the other portion of the strips the native vegetation is already preserved.

Regarding the area to be respected outside the recovery ranges, Table 8 reveals that the area occupied by native forest in the APPs increased in relation to 2008, therefore, its current situation should be maintained. Given that part of the native vegetation is within the 8-meter strips, it is observed that the area outside these strips that contains this coverage and, therefore, must be respected, reaches $8,934.12 \mathrm{~m}^{2}$.

Adding this area to the total extension of the 8 meters strips next to the watercourses that must be preserved, with $3,716.85 \mathrm{~m}^{2}$, it is concluded that the total area to be respected in the property results in $12,650.97 \mathrm{~m}^{2}$, the which represents $59.77 \%$ of the total area of its PPAs, which is $21,116.38 \mathrm{~m}^{2}$. In the rest of its PPAs, agroforestry activity can be maintained.

\subsection{PROPERTY RATED GOOD}

The data found on the use and cover of the PPAs of the property rated Good, in 2018 and in 2008, are shown in Table 10. 
Table 10 | Use of PPAs in the property rated Good in the PPA parameter.

\begin{tabular}{|c|c|c|c|c|}
\hline & \multicolumn{2}{|c|}{ Status in 2018} & \multicolumn{2}{c|}{ Status in 2008} \\
\hline USE OF PPAS & Area $\left(\mathrm{m}^{2}\right)$ & Percentage & Area $\left(\mathrm{m}^{2}\right)$ & Percentage \\
\hline NATIVE FOREST & $23,514.43$ & $74.96 \%$ & $16,315.43$ & $52.01 \%$ \\
\hline PASTURE & $5,760.54$ & $18.36 \%$ & $11,396.03$ & $36.33 \%$ \\
\hline SWAMP & $2,091.77$ & $6.66 \%$ & $3,655.27$ & $11.65 \%$ \\
\hline
\end{tabular}

Source: Research data (2019).

In 2008, its PPAs had a pasture area, considered a consolidated rural area, in addition to native and wetland, which is configured as a PPA, in accordance with Article 4, item VI of the New Forest Code. Regarding its use in 2018, there was an increase in its native vegetation, while the wetland area and the area destined to pasture reduced.

Considering the existence of a consolidated rural area, and that the property has between 3 and 4 fiscal modules, a 15-meter strip in the watercourse present in the property, starting from the edge of the channel of the regular bed of the watercourse, should be recomposed. The property also has two other areas considered PPAs, one swamp (palm swamp) and two springs. In relation to the first, the strip to be recomposed is 30 meters, according to article 61-A, paragraph 7, item I of the New Forest Code, while the recovery of the spring must be of a 15 meters radius in its surroundings, as determined in paragraph 5 of the same article. Table 11 shows the use and cover of these strips to be recomposed.

Table 11 | Use of recovery strips in the property rated Good in the PPA parameter.

\begin{tabular}{|l|l|c|}
\hline Use of the strips & Area $\left(\mathrm{m}^{2}\right)$ & Percentage \\
\hline NATIVE FOREST & $5,350.77$ & $100 \%$ \\
\hline
\end{tabular}

Source: Research data (2019).

The data found reveal that these strips, which add up to $5,350.77 \mathrm{~m}^{2}$, are already completely covered by native vegetation, which is why no recovery is necessary, since they are already preserved.

Considering that there was an increase in the area occupied by native forest in the PPAs compared to 2008, its current situation (2018) must be respected. Therefore, in this property, the portion currently covered by native vegetation must be respected, together with the area occupied by the swamp, which is considered APP. Together, these areas reach $25,606.20 \mathrm{~m}^{2}$, representing $81.63 \%$ of the extension of the property's PPAs, with $31,366.74 \mathrm{~m}^{2}$. In the rest of its area, intended for pasture, livestock activity can be maintained.

\subsection{PROPERTY RATED EXCELLENT}

The data found on the situation of the PPA in the property rated Excellent, in 2018 and 2008, are shown in Table 12.

Table 12 | Use of PPA in the property rated Excellent in the PPA parameter.

\begin{tabular}{|c|c|c|c|c|}
\hline & \multicolumn{2}{|c|}{ Status in 2018} & \multicolumn{2}{c|}{ Status in 2008} \\
\hline PPA USE & Area $\left(\mathrm{m}^{2}\right)$ & Percentage & Area $\left(\mathrm{m}^{2}\right)$ & Percentage \\
\hline NATIVE FOREST & $24,669.18$ & $98.37 \%$ & $24,459.36$ & $97.54 \%$ \\
\hline CORN & 408.20 & $1.63 \%$ & 618.00 & $2.46 \%$ \\
\hline
\end{tabular}

Source: Research data (2019). 
In this property, its PPA contained native forest in almost all its extension in 2008, and a small area with agricultural activity, which characterizes a consolidated rural area. Its situation in 2018 has hardly changed, only its use proportions varied.

The property has an area of less than 1 fiscal module, which requires the recovery of a 5-meter strip, counting from the margin of the watercourse present in the property, as shown in Table 1. Table 13 represents the use and cover of this strip.

Table 13 | Use of the recovery strips in the property rated Excellent in the PPA parameter.

\begin{tabular}{|c|c|c|}
\hline Use of the strips & Area $\left(\mathrm{m}^{2}\right)$ & Percentage \\
\hline NATIVE FOREST & $1,804.04$ & $100 \%$ \\
\hline
\end{tabular}

Source: Research data (2019).

Given that the recovery strip, which has $1,804.04 \mathrm{~m}^{2}$, is already preserved, being fully occupied by native vegetation, no recovery is necessary.

Therefore, with an increase in native vegetation compared to 2008, the area of the PPA to be protected is that currently containing this coverage, with $24,669.18 \mathrm{~m}^{2}$, corresponding to $98.37 \%$ of its total extension, of $25,077.36 \mathrm{~m}^{2}$. Agroforestry activity may be maintained in the rest of the PPA, and new suppressions are prohibited.

\subsection{LIMITS TO THE RECOVERY IMPOSED BY ARTICLE 61-B OF THE NEW FOREST CODE}

As shown in Table 1, Article 61-B of the New Forest Code imposes limitations on the maximum percentage of the property that the strips to be recomposed, provided for in Article 61-A, can represent. However, in none of the properties where recovery is necessary, the percentages were reached, as shown in Table 14 . The legal limits vary between $10 \%$ and $20 \%$, while the highest percentage found in the surveyed properties was $1.12 \%$.

Table 14 | Percentages of property areas to be recomposed in the strips provided for in Article 61-A of the New Forest Code.

\begin{tabular}{|c|c|c|c|c|c|}
\hline $\begin{array}{c}\text { Property } \\
\text { rate }\end{array}$ & $\begin{array}{c}\text { Total area of the } \\
\text { property }\left(\mathrm{m}^{2}\right)\end{array}$ & $\begin{array}{c}\text { Area of the strips } \\
\text { according to article } \\
\text { 61-A of the } F C\left(\mathrm{~m}^{2}\right)\end{array}$ & $\begin{array}{c}\text { Percentage of the } \\
\text { property area that } \\
\text { the strips represent }\end{array}$ & $\begin{array}{c}\text { Area of the strips not } \\
\text { covered by native vegeta- } \\
\text { tion, to be recomposed }\end{array}$ & $\begin{array}{c}\text { Percentage of the } \\
\text { property area to } \\
\text { be recomposed }\end{array}$ \\
\hline VERY BAD & $198,205.86$ & $2,234.85$ & $1.02 \%$ & $2,234.85$ & $1.12 \%$ \\
\hline BAD & $304,418.94$ & $1,846.14$ & $0.60 \%$ & $1,846.14$ & $0.60 \%$ \\
\hline REGULAR & $271,113.76$ & $3,716.85$ & $1.37 \%$ & $2,162.97$ & $0.79 \%$ \\
\hline GOOD & $600,852.07$ & $5,350.77$ & $0.89 \%$ & 0.00 & $0.00 \%$ \\
\hline EXCELLENT & $158,176.30$ & $1,804.04$ & $1.11 \%$ & 0.00 & $0.00 \%$ \\
\hline
\end{tabular}

Source: Research data (2019). 


\section{DISCUSSION OF DATA}

The application of the transitional rules of the New Forest Code, related to consolidated rural areas, to the situation of the properties' PPAs, revealed a significant variation in the area of the PPAs of each property that must remain respected. To illustrate the situation, Table 15 shows the following data for each property: percentages of PPAs with native vegetation in 2008 and 2018, in relation to the measures provided for in the general rule of article 4, item I of the New Forest Code; area of PPAs that must be recomposed in the strips provided for in article 61-A of the Code; area of PPAs to be respected outside these strips; percentage of the area of the PPAs that must be respected after the application of the Code's rules, in comparison with the general protection measures.

Table 15 | Evolution of the native vegetation coverage in PPAs and areas to be preserved and recomposed based on the rules of the New Forest Code.

\begin{tabular}{|c|c|c|c|c|c|}
\hline Property Rate & $\begin{array}{c}\text { Percentage of } \\
\text { PPAs with native } \\
\text { vegetation in 2008 }\end{array}$ & $\begin{array}{c}\text { Percentage of } \\
\text { PPAs with native } \\
\text { vegetation in 2018 }\end{array}$ & $\begin{array}{c}\text { Area of PPAs to be } \\
\text { recomposed } \\
\text { according to article } \\
61-A \text { of } F C\left(m^{2}\right)\end{array}$ & $\begin{array}{c}\text { Area to be respected } \\
\text { outside the strips } \\
\text { determined by art. } \\
61-A \text { of FC }\left(\mathrm{m}^{2}\right)\end{array}$ & $\begin{array}{c}\text { Percentage of PPAs } \\
\text { to be respected, } \\
\text { applying the } \\
\text { FC rules }\end{array}$ \\
\hline VERY BAD & $0.00 \%$ & $0.00 \%$ & $2,234.85$ & 0.00 & $11.72 \%$ \\
\hline BAD & $0.00 \%$ & $0.00 \%$ & $1,846.14$ & 0.00 & $5.10 \%$ \\
\hline REGULAR & $46.00 \%$ & $49.70 \%$ & $2,162.97$ & $8,934.12$ & $59.77 \%$ \\
\hline GOOD & $52.01 \%$ & $74.96 \%$ & 0.00 & $18,163.66$ & $81.63 \%$ \\
\hline EXCELLENT & $97.54 \%$ & $98.37 \%$ & 0.00 & $22,865.14$ & $98.37 \%$ \\
\hline
\end{tabular}

Source: Research data (2019).

The result of the total area of the PPAs to be respected, in relation to its measures according to the general rule of article 4 of the Code, varied between $5.10 \%$ and $98.37 \%$, that is, an amplitude of $93.27 \%$.

The two properties in which there is no native vegetation, and neither there was in 2008, rated Very Bad and Bad, were those with the lowest percentages, with $11.72 \%$ and $5.10 \%$, respectively. In these, the only portions to be respected will be those of the recovery strips next to the watercourses, while all the rest of its PPAs, as they are a consolidated rural area, may continue to be used in agroforestry activities.

In the other three properties, rated Regular, Good and Excellent, in addition to the recovery strips, the portion that currently contains native vegetation should also be preserved, resulting, respectively, in $59.77 \%, 81.63 \%$ and $98.37 \%$ of the total of their PPAs that must be respected. Of the three, only the one rated Regular does not have the restoration strips already fully covered by native vegetation, but only a part, which must be recomposed.

It was also observed that, in these three properties with better rates, the area covered by native forest in their PPAs has increased since 2008. This evolution of the preserved area ended up representing the corresponding increase in the portion to be respected. This is because Article 61-A of the New Forest Code only authorizes the continued use of areas that were intended for agroforestry activities on July 22,2008 , but not the return of use in areas where activities were stopped after that, in which the advance of native vegetation was observed.

Therefore, the results of the cases studied indicate that the greater the area of PPAs preserved, and the more this portion has increased since 2008, the greater the area of PPAs to be respected will be. On the other hand, the lack of native vegetation in the PPAs, with the entire area destined to agroforestry activities, and the maintenance of this situation since 2008 , has resulted in the need to respect only the recovery strip along the watercourse.

Thus, the application of the rules of the New Forest Code relating to PPAs, notably their temporary provisions regarding the consolidated rural area, entails different obligations, and even paradoxical 
ones, for the owners. In general, it was observed that those that most preserved their native vegetation are subject to greater restrictions on the use of the property, with greater areas to be respected, while to those that most suppressed it, the area that can continue to be used is larger, and its variation may depend on the size of the property.

Therefore, it is possible to affirm that the results found confirmed the hypothesis of the present research. In properties where the consolidated rural area occupies a large portion of their PPAs, which was observed especially in those rated Very Bad and Bad, the area of their PPAs to be respected was significantly reduced, representing only $11.72 \%$ and $5.10 \%$ of their respective total areas.

The situation of these properties demonstrated the direct impact of linking the extension of the recovery strips exclusively to the size of the property, disregarding the width of the watercourse. In both, these strips represent the only portion of their PPAs to be respected.

On the other hand, the property rated Excellent, which in 2008 had consolidated rural area in only $2.46 \%$ of its PPAs, must respect almost all its extension, $98.37 \%$.

When comparing the classifications of the properties studied in the PPA parameter, used in the present work for their draw, with the general scores obtained by them in the project "Sustainability in milk producing rural properties", no relation was observed. As shown in Table 1, the project parameters evaluated: Waste, Water, PPA, Legal Reserve, Pesticides and Fertilizers, Declivity, Erosion, Burnings and Land Use.

The general score indicated that those rated Very Bad and Good in the PPA parameter were the best classified, both with 71.25 points, followed by those rated Bad and Regular, with 67.25 points, the worst score being given precisely to that rated Excellent, with 61.25 points. This shows that the situation of the properties' PPAs is not directly related to the practices adopted by the owners regarding the other sustainability parameters evaluated. It is possible that the use and conservation of PPAs are the result of vicissitudes, such as the location of the watercourse on the property or the production system used, and not practices deliberately focused on sustainability.

Comparing the results of the recovery areas found in this research with other works, Bonamigo et al. (2017) analyzed 68 properties in the Santa Catarina state southern plateau. In rural properties that have between 1 and 2 fiscal modules, and that present a consolidated rural area, they found that the area to be recomposed represents, on average, $9 \%$ of the property area. For those properties that have between 2 and 4 fiscal modules, the average to be recomposed corresponds to $17.2 \%$ of the property.

Okuyama et al. (2017), in a study with the same objective carried out on 147 family farms located in the Central-Eastern and Southeast regions of Paraná, observed that the areas to be recovered in the properties' PPAs represent, on average, $4.9 \%$ of the real estate area.

The percentages higher than those found in the present study may result from the amount of PPAs present in the properties, as highlighted by Okuyama et al. (2017), as well as the possible presence of different sorts of PPA, which imply different recovery measures. The referred studies also did not consider the portions of the recovery strips that may already be occupied by native vegetation, that do not need to be recomposed, which could imply a decrease in the percentages.

The high presence of areas destined to pasture in PPAs, and reduced native vegetation coverage, observed especially in properties rated Very Bad and Bad, can cause damage not only to the environmental function of their PPAs, but also to milk production.

In a study on water quality in 15 milk producing rural properties in the TV, Bortoli et al. (2017) found that cattle are raised loose, with free access to the place of watering, which is carried out in watercourses on the properties where this resource was present. Access to these sites was related to the presence 
of pasture areas and potters close to the watercourses, a characteristic observed, in the present study, in properties rated Very Bad, Bad and Regular, which present pasture areas both in the PPAs and in the recovery strips along the watercourses.

Bortoli et al. (2017) observed that this access result in trampling on the margin, causing siltation, compaction and erosion, in addition to contamination of the water with coliforms by the defecation of cattle on the site, which affects water quality and contributes to the spread of diseases. The absence of native vegetation also contributes to the transport of waste to water resources, increasing contamination.

The results of the water samples analyzed in that research showed that, of the 15 properties studied, the 5 in which the samples met legal quality standards present native vegetation in a proportion greater than $50 \%$ of their PPAs, in addition to revealing an association between the variables coliform, present in the samples, and vegetation cover of PPAs (BORTOLI et al., 2017).

Bortoli et al. (2017) also stated that the water quality impacts on animal health and milk production, since the observed contamination, in addition to reducing production, increases the risk of disease spread.

Corroborating this study, in research on the tree community of riparian forests in three milk producing properties in the Taquari Valley, Markus et al. (2018) verified that the diversity found was lower than that observed by studies in other regions of the state. They concluded that the high pressure caused by cattle grazing and trampling, verified in the study, may be influencing on this reduction in tree diversity.

Therefore, the development of activities on the properties object of the present study, with the raising of cattle for milk production, when associated with the occupation of areas next to watercourses for the management and grazing of the cattle, and the consequent animal watering on the site, leads to deterioration of the margin, suppression of vegetation, contamination of the water resource and consequent damage to milk productivity.

Thus, it can be concluded that banning access of cattle to watercourses and restoring riparian forest with native vegetation are determining factors for the restoration of plant diversity, recovery of the margin conditions and avoid its erosion, as well as to improve water quality.

Considering the results found, it is indicated that the producers do not limit themselves to comply with the legal minimum required, especially when it is only necessary to recompose the strips next to watercourses, whose maximum percentage found in this research reached $11.72 \%$ of the PPAs total area. The recovery of at least $50 \%$ of the PPAs can contribute decisively for the water resource to reach satisfactory quality standards, leading to a gain in milk productivity.

\section{FINAL CONSIDERATIONS}

Although the New Forest Code has implemented a direct reduction in the area of the PPA to be protected along watercourses, since the widths of the protection strips are now counted from the channel of the regular bed, and no longer from their highest level, as provided for in the New Forest Code of 1965, the results of the present study demonstrate that this reduction can be much more significant. When the transitional rules regarding consolidated rural areas were applied to the properties studied, it was observed that the smallest area to be respected represents only $5.10 \%$ of the PPAs of the property rated Bad.

Consequently, the application of the Code's transitional rules can result in such a small percentage to be respected, that it is unable to fulfill the socio-environmental functions of the PPA, as shown by the studies mentioned above. 
In milk producing rural properties, direct access by cattle to water courses for watering can cause various damage to vegetation and soil on the margins, in addition to contamination of water resources. Banning cattle access and the appropriate recovery of native vegetation in the PPA of watercourses are decisive factors for the vegetation and margin restoration and may contribute to the water reaching satisfactory quality standards and consequent gain in milk productivity.

\section{REFERENCES}

BONAMIGO, A. et al. Changes in permanent preservation areas in rural properties of the Santa Catarina state southern plateau according to the laws n. 4,771 and 12,651. Ciência Rural, Santa Maria, 47, n. 2, 2017. Disponível em: <http:// www.scielo.br/scielo.php?script=sci_arttext\&pid=S0103-84782017000200933>. Acesso em: 23 maio 2019.

BORTOLI, J. et al. A qualidade da água de dessedentação animal e a preservação das áreas de preservação permanente. Revista Ibero-americana de Ciências Ambientais, v. 8, n. 3, p. 170-179, 2017.

BRASIL. Lei n 4.771, de 15 de setembro de 1965. Brasília, DF, 1965.

BRASIL. Constituição (1988). Constituição da República Federativa do Brasil de 1998. Brasília, DF, 1998.

BRASIL. Decreto 6.514, de 22 de julho de 2008. Brasília, DF, 2008.

BRASIL. Lei no 12.651, de 25 de maio de 2012. Brasília, DF, 2012a.

BRASIL. Decreto 7.830, de 17 de outubro de 2012. Brasília, DF, 2012f.

BRASIL. Supremo Tribunal Federal. Ação Direta de Inconstitucionalidade no 4902. Requerente: Procurador-Geral da República. Requeridos: Presidente da República e Congresso Nacional. Ministro Relator: Luiz Fux. Brasília, 18 de janeiro de 2013. Disponível em: <http://redir.stf.jus.br/estfvisualizadorpub/jsp/consultarprocessoeletronico/ ConsultarProcessoEletronico.jsf?seqobjetoincidente=4355128>. Acesso em: 2 maio 2019.

COMISSÃO Mundial sobre Meio Ambiente e Desenvolvimento. Nosso futuro comum. 2. ed. Rio de Janeiro: Fundação Getúlio Vargas, 1991.

COSTA, B. S.; GABRICH, L. M. S. Área rural consolidada e a anistia aos danos ambientais no Código Florestal Brasileiro: retrocesso legitimado pelo STF. Direito em Debate, Ijuí, ano XXVII, n. 50, p. 102-114, jul. 2018. Disponível em: <https://www.revistas.unijui.edu.br/index.php/revistadireitoemdebate/article/view/8145>. Acesso em: 30 abr. 2019.

COSTA, T. C. C. da; SOUZA, M. G. de; BRITTES, R. S. Delimitação e caracterização de Áreas de Preservação Permanente, por meio de um Sistema de Informações Geográficas (SIG). In: VIII SIMPÓSIO BRASILEIRO DE SENSORIAMENTO REMOTO, 1996, Salvador. Anais... São Paulo: INPE. Disponível em: <http://marte.sid.inpe.br/ col/sid.inpe.br/deise/1999/01.27.16.17/doc/T48.pdf>. Acesso em: 15 ago. 2019.

FEIX, R. D.; JORNADA, M. I. H. da; GASPERI, E. de. Aglomeração produtiva de laticínios na região do Corede Vale do Taquari. Porto Alegre: FEE, CEES e NAS, 2015. Disponível em: <http://www.fee.rs.gov.br/publicacoes/ relatorios/>. Acesso em: 10 out. 2016.

FOOD AND AGRICULTURE ORGANIZATION OF THE UNITED NATIONS. Statistic Division. 2019. Disponível em: $<$ http://www.fao.org/faostat/en/\#data>. Acesso em: 04 jul. 2019.

FUNDAÇÃO DE ECONOMIA E ESTATÍSTICA. Aglomeração produtiva de laticínios na região do Corede Vale do Taquari. 2015a. Disponível em: <https://www.fee.rs.gov.br/wp-content/uploads/2016/06/201606069-laticiniosvale-do-taquari-relatorio1.pdf >. Acesso em: 10 jan. 2018.

FUNDAÇÃO DE ECONOMIA E ESTATÍSTICA. Produção de leite por Corede no ano de 2014. 2015b. Disponível em: <http://www.fee.rs.gov.br/feedados/\#! pesquisa=1>. Acesso em: mar. 2018.

HERMANN, M. F. Localização da região do Vale do Taquari com a determinação da quantidade de propriedades avaliadas em cada município. Lajeado: Univates, 2018. (elaboração de mapa). 
INSTITUTO BRASILEIRO DE GeOgRAFIA E ESTATístICA. Pesquisa Pecuária Municipal. 2017. Disponível em: <https://www.ibge.gov.br/estatisticas/economicas/agricultura-e-pecuaria/9107-producao-da-pecuariamunicipal.html?t=resultados>. Acesso em: 04 jul. 2019.

INSTITUTO BRASILEIRO DE GeOgrafiA e eStATístICA. Produção da Pecuária Municipal 2017. Rio de Janeiro: IBGE, 2018. Disponível em: <https://biblioteca.ibge.gov.br/visualizacao/periodicos/84/ppm_2017_v45_br_ informativo.pdf >. Acesso em: 04 jul. 2019.

INSTITUTO NACIONAL DE COLONIZAÇÃO E REFORMA AGRÁRIA. Tabela com os módulos ficais dos municípios. 2013. Disponível em: <http://www.incra.gov.br/tabela-modulo-fiscal>. Acesso em: 15 abr. 2019.

MARKUS, E. et al. Análise estrutural da comunidade arbórea da mata ciliar de três cursos d'água em propriedades produtoras de leite no Vale do Taquari, RS. Pesquisas, Botânica, São Leopoldo, n. 71, p. 63-76. Disponível em: <http://www.anchietano.unisinos.br/publicacoes/botanica/botanica.htm>. Acesso em: 23 maio 2019.

OKUYAMA, K. K. et al. Adequação de propriedades rurais ao Código Florestal Brasileiro: estudo de caso no estado do Paraná. Revista Brasileira de Engenharia Agrícola e Ambiental, Campina Grande, v. 16, n. 9, p. 10151021, 2012. Disponível em: <http://www.scielo.br/scielo.php?pid=S1415-43662012000900013\&script=sci_ abstract\&tlng=pt>. Acesso em: 22 maio 2019.

PESSI, D.; REMPEL, C.; HAETINGER, C. Diagnóstico do uso da terra em Áreas de Preservação Permanente de pequenas propriedades rurais produtoras de leite no Vale do Taquari/RS - Brasil. Revista Espacios, Bogotá, v. 38, n. 22, p. 1-10, 2017.

REMPEL, C. et al. Proposta metodológica de avaliação da sustentabilidade ambiental de propriedades produtoras de leite. Tecno-lógica, Santa Cruz do Sul, v. 16, n. 1, p. 48-54, 2012.

REMPEL, C. et al. Sustentabilidade de propriedades produtoras de leite. Projeto de Pesquisa. Lajeado: Univates, 2017.

RODRIGUES, G. S.; CAMPANHOLA, C.; KITAMURA, P. C. Avaliação de impacto ambiental da inovação tecnológica agropecuária: Ambitec-Agro. Jaguariúna: Editora Embrapa Meio Ambiente, 2003. 95p.

VERONA, L. F. Avaliação de sustentabilidade em agroecossistemas de base familiar e em transição agroecológica na região sul do Rio Grande do Sul. 2008. 96 f. Tese (doutorado) - Universidade Federal de Pelotas. Programa de Pós-graduação em Agronomia. Pelotas: UFPel, 2008. 